\title{
Expantion of distribution range of the Greater Grison (Galictis vittata) in México
}

\section{Expansión del área de distribución del grisón (Galictis vittata) en México}

\author{
Carlos Contreras-Díaz ${ }^{1}$, Leroy Soria-Díaz ${ }^{2 *}$, Claudia C. Astudillo-Sánchez ${ }^{1}$, Hublester Domínguez-Vega ${ }^{3}$, Yuriana Gómez-Ortiz, and \\ LUIS Martínez-García ${ }^{2}$ \\ ${ }^{1}$ Facultad de Ingeniería y Ciencias, Centro Universitario Victoria, Universidad Autónoma de Tamaulipas. Adolfo López Mateos, C P. \\ 87149, Ciudad Victoria. Tamaulipas, México. Email: a2133010122@alumnos.uat.edu.mx (CC-D), ccastudillo@docentes.uat.edu. \\ $\underline{\mathrm{mx}}$ (CCA-S). \\ ${ }^{2}$ Instituto de Ecología Aplicada, Universidad Autónoma de Tamaulipas, Av. División del Golfo No. 356. Col. Libertad, C P. 87019, \\ Ciudad Victoria. Tamaulipas, México. Email: leroysoriadiaz@gmail.com, lesoria@uat.edu.mx (LS-D), martinez.garcialuisfer@ \\ gmail.com (LM-G). \\ ${ }^{3}$ División de Desarrollo Sustentable, Universidad Intercultural del Estado de México, Libramiento Francisco Villa SN, C P. 50640, San \\ Felipe del Progreso. Estado de México, México. Email: hublester.dvega@gmail.com (HD-V), yurianagomezortiz@gmail.com (YG-O). \\ ${ }^{*}$ Corresponding author
}

The potential distribution of the Greater Grison, Galictis vittata, reaches east-central México including the southern portion of Tamaulipas state. However, there are no geographical records that confirm this potential range limit. Our study documents the first record of the Greater Grison photographed by camera traps at "El Cielo" Biosphere Reserve, Tamaulipas State, México. We installed 26 camera traps at "El Cielo" Biosphere Reserve. The cameras were programmed to take pictures and with the date and hour of each photo recorded automatically. Also, we created a map, which combined the Greater Grison's potential distribution and published occurrence records, to overlay on our new sightings in "El Cielo". One camera trap recorded two photos of a Greater Grison at "El Cielo" Biosphere Reserve, within a preserved pine-oak forest environment. These two records represent the only confirmed sightings of the Greater Grison in Tamaulipas state and they are located 64.4 $\mathrm{km}$ northwest of the nearest estimated potential distribution and $186 \mathrm{~km}$ north of the northern-most sighting in southern San Luis Potosí. The record of our study expand both the original potential distribution and the known distribution of this species toward the northwest and north, respectively. The sightings also increase the known elevation limit of the species in México from 1,500 to 1,790 m. We believe that the occurrence of Greater Grison at "El Cielo" is not unusual because this site has the conditions and habitat that are suitable to the distribution of this species.

Key words: Biosphere reserve; Mustelidae; northeast México; Sierra Madre Oriental.

La distribución potencial del gran grisón, Galictis vittata, llega al centro y este de México, incluida la parte sur del estado de Tamaulipas. Sin embargo, no hay registros geográficos que confirmen este límite. El presente estudio documenta el primer registro del gran grisón fotografiado por trampas cámara en la Reserva de la Biosfera "El Cielo", Tamaulipas, México. En el área de estudio se instalaron 26 trampas cámara que fueron programadas para obtener fotografías con la hora y fecha impresa. También se realizó un mapa en el que se integró la distribución potencial del grisón, los registros de ocurrencia publicados y los registros fotográficos de “El Cielo". Una trampa cámara registró dos fotografías del gran grisón en la Reserva de la Biosfera "El Cielo", dentro de un bosque de pino-encino conservado. Los dos registros representan el único avistamiento confirmado para el grisón en Tamaulipas, y están localizados a $64.4 \mathrm{~km}$ al noroeste de la distribución potencial estimada y a 186 km al norte del registro confirmado en el sur del estado de San Luis Potosí. Los registros de este estudio expanden tanto la distribución potencial como la distribución conocida del grisón hacia el noroeste y al norte, respectivamente, y también, aumentan el límite de elevación conocido en México de 1,500 a 1,790 m. La presencia del gran grisón en “El Cielo", se debe probablemente a que este sitio tiene las condiciones de hábitat para que se pueda distribuir esta especie.

Palabras clave: Mustelidae; noreste de México; reserva de la biosfera; Sierra Madre Oriental.

(C) 2020 Asociación Mexicana de Mastozoología, www.mastozoologiamexicana.org

The Greater Grison, Galictis vittata (Shreber, 1776), is a medium-sized mustelid with an elongated body and distinctively short legs (Álvarez-Castañeda et al. 2015). Its potential distribution indicate it could range from the southeastern portion of México including the Yucatán peninsula, south through Central America, and throughout the northern half of South America (Yensen and Tarifa 2003; Tarifa et al. 2010; Bornholdt et al. 2013). It has been recorded in tropical forests, rainforests, grasslands, arid regions, tropical dry forests, coffee plantations and secondary vegetation (Estrada et al. 1993; Gallina et al. 1996; De la Torre et al. 2009; Hodge and Arbogast 2016; Mandujano et al. 2018).

The Greater Grison is of special interest because it is one of the least-known mammals in the Americas; because of the low numbers of studies or records reporting its pres- 
ence, we know very little about the biology and ecology of this species throughout its range (Tarifa et al. 2010; Hernández-Hernández et al. 2018).

In México, the laws of faunal protection consider Galictis vittata to be an endangered species (SEMARNAT 2010). According to our literature search, the potential distribution of Greater Grison in México includes 11 states located at the east and southeast of the country (Escalona-Segura et al. 2002; Ramírez-Pulido et al. 2005; González-Christen 2008; Olguín-Monroy et al. 2008; De la Torre et al. 2009; Hernández-Hernández et al. 2018; Mandujano et al. 2018). In México, the Greater Grison lives at altitudes ranging from sea level to $1,500 \mathrm{~m}$ above sea level, but mostly below 500 $\mathrm{m}$ (Yensen and Tarifa 2003). Although the potential distribution of the Greater Grison reaches into the extreme southeastern portion of Tamaulipas state (Yensen and Tarifa 2003; Cuarón et al. 2016), there were no records confirming its presence in this state (Vargas-Contreras and Hernández-Huerta 2001), until now. In this study, we submit the first confirmed record of occurrence of the Greater Grison (Galictis vittata) in Tamaulipas state, México, expanding its potential and known distribution limits.

This study was conducted at "El Cielo"Biosphere Reserve, located in the Northeast of México, in Tamaulipas state and is part of the bio-geographical region of the "Sierra Madre Oriental" (SMO). This reserve is an important zone of transition between the Nearctic and the Neotropical regions, with altitudes ranging between 100 and 2,300 $\mathrm{m}$ that provide different environmental conditions and different types of vegetation (Steinberg et al. 2014). From December 2017 to January 2019 we installed 26 camera traps (Scoutguard HCO model SG565) at "El Cielo". The cameras were one km apart, in two types of habitat: cloud forest and pine-oak forest and were programmed to take pictures, with the date and hour of each photo recorded automatically.

We created a map, which combined the Greater Grison's potential distribution (Cuarón et al. 2016) and published occurrence records (Global Biodiversity Information Facility 2019; database updated until January 2019), to overlay on our new sightings in "El Cielo."

One camera trap recorded two photos of a Greater Grison in 2018; the first on 17 July at $1818 \mathrm{H}$ and the second on 1 November at $1052 \mathrm{H}$ (Figure 1). These photos clearly

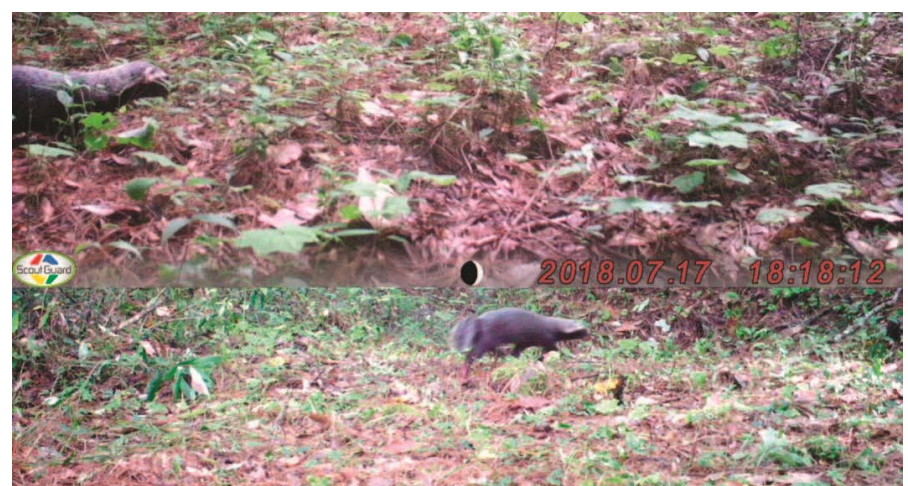

Figure 1. Photographic evidence of the Grater Grison (Galictis vittata) on "El Cielo" Biosphere Reserve Tamaulipas, México, in a pine-oak forest. show the typical color pattern of the species: blackish marbled gray dorsally with a white stripe starting at the forehead, passing under the ears and above the eyes, and ending at the shoulders. Anatomically, the limbs are very small and the tail is short, as is typical of the Greater Grison (Figure 1; Álvarez-Castañeda et al. 2015). The camera trap that took both pictures was positioned at $23^{\circ} 2^{\prime} 44.70^{\prime \prime} \mathrm{N},-99^{\circ} 15^{\prime}$ $45.90^{\prime \prime} \mathrm{W}$ at an elevation of $1,790 \mathrm{~m}$ (Figure 2). It was within a preserved pine-oak forest environment (mostly Pinus patula, P. pseudostrobus, Quercus germana, Q. affinis and $Q$. polymorpha; González-Medrano 2005; Pérez and ValenciaA. 2017) and very close to the cloud forest (approximately $200 \mathrm{~m}$ away).

These two records in the "El Cielo" Biosphere Reserve represent the only confirmed sightings of the Greater Grison in Tamaulipas, México. They are located $64.4 \mathrm{~km}$ northwest of the nearest estimated potential distribution and $186 \mathrm{~km}$ north of the northern-most sighting in southern San Luis Potosí (Figure 2). Together, these two sightings expand both the original potential distribution and the known distribution of this species toward the northwest and north, respectively. The sightings also increase the known elevation limit of the species in México from 1,500 (Yensen and Tarifa 2003) to 1,790 masl. However, another study in Colombia sighted a Greater Grison at 2,200 m (Escobar-Lasso and Guzmán-Hernández 2014).

The San Luis Potosí specimen of Galictis vittata mentioned above, was collected from the Xilitla locality $\left(21^{\circ}\right.$ $23^{\prime} 10^{\prime \prime} \mathrm{N},-98^{\circ} 59^{\prime} 24^{\prime \prime} \mathrm{W}$ ), was preserved and deposited on the Louisiana state University Museum of Natural Science, Mammal Collection. Record ID: urn: catalog: LSUMZ: Mammals: 2769. Source: http://ipt.vertnet.org:8080/ipt/resource. do? $r=$ Isumz_mammals (published on 03-19-2015).

Other mustelid species have been recorded in previous studies conducted at the "El Cielo" (e. g., Eira barbara senex and Mustela frenata frenata; Vargas-Contreras and Hernández-Huerta 2001), but the Greater Grison had

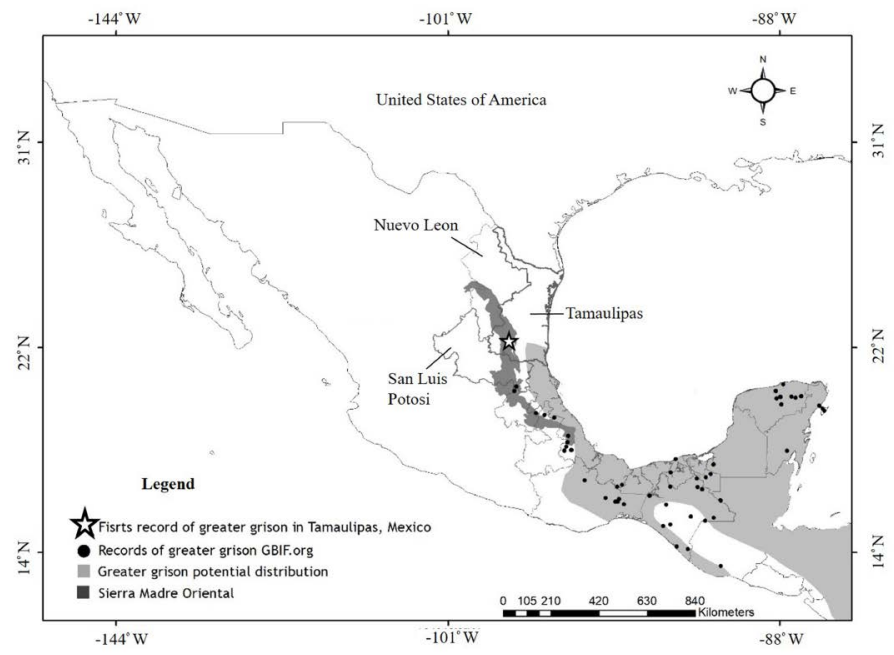

Figure 2. First record of the Greater Grison (Galictis vittata) for the Tamaulipas state, México. White star = first record of Greater Grison in Tamaulipas, México; black dots = records of the Greater Grison in GBIF.org; light gray = potential geographic distribution of Greater Grison; dark gray = Sierra Madre Oriental. 
not been mentioned before, not even as an anecdotal record. We believe that the occurrence of Greater Grison at "El Cielo" is due to that the reserve has the conditions and habitat that are suitable to the distribution of this species (cloud forest, tropical forest and grassland). Other research in México, have registered this species in tropical forests, rainforests, grasslands, cloud forest, arid regions, tropical dry forests, coffee plantations and secondary vegetation (Estrada et al. 1993; Gallina et al. 1996; De la Torre et al. 2009; Mandujano et al. 2018). On the other hand, "El Cielo" is undergoing a consistent process of plant regeneration that started 35 years ago when the biosphere reserve was established by decree (1985) and forestry exploitation stopped completely (Steinberg et al. 2014). Maybe now, with less human activity and better conservation of the reserve, it will be possible for species like the Greater Grison can reach these areas. Furthermore, the geographical position of "El Cielo" within the eastern mountain range, Sierra Madre Oriental, allows the Reserve to function as an important biological corridor, connecting the wild fauna populations of Nuevo Leon and San Luis Potosi states (Steinberg et al. 2014), and opening the possibility for species from other States to arrive at Tamaulipas (Figure 2). Finally we want to highlight that camera trap are an efficient tool to discovering new species and document the expansion of species into new areas, as described in our writing.

\section{Acknowledgements}

The authors thank to F. Caballero-Rico, E. BerronesBenítez (field guide) and Mr. Moisés for allowing us to enter "ejido San José" at El Cielo Biosphere Reserve. We thank"Universidad Autónoma de Tamaulipas" (Project UAT/PFI2015$15)$ and the Higher Education Teacher's Professional Development Program, "PRODEP" (UAT-PTC-221/511-6/17-8212) for the funding granted to this research work. We also thank R. J. Smith for the English edition.

\section{Literature cited}

Álvarez-Castañeda, S. T., T. Álvarez, and N. González-Ruiz. 2015. Keys for identifying mexican mammals. Impresiones Pandora S. A. de C. V. Jalisco, México.

Bornholdt, R., K. Helgen, K. Klaus-Peter, L. Oliveira, M. Lucherinı, AND E. EIZIRIK. 2013. Taxonomic revision of the genus Galictis (Carnivora: Mustelidae): species delimitation, morphological diagnosis, and refined mapping of geographical distribution. Zoological Journal of the Linnean Society 167:449-472.

Cuarón, A. D., F. Reid, J. F. González-Maya, and K. Helgen. 2016. Galictis vittata. En: IUCN 2016. The IUCN Red List of Threatened Species: e.T41640A45211961. http://dx.doi. org/10.2305/IUCN.UK.2016-1.RLTS.T41640A45211961.enDownloaded on January 07, 2019.

De La Torre, J., C. Muech, and M. Arteaga. 2009. Nuevos registros de grisón (Galictis vittata) para la selva Lacandona, Chiapas, México. Revista Mexicana de Mastozoología 13:109114.
Escalona-Segura, G., J. Vargas-Contreras, and L. Interián-Sosa. 2002. Registros importantes de mamíferos para Campeche, México. Revista Mexicana de Mastozoología 6:166-170.

Escobar-Lasso, S., and C. Guzman-Hernández. 2014. El registro de mayor altitud del Hurón Mayor Galictis vittata, con notas sobre su presencia y conservación dentro del departamento de Caldas, en la región andina de Colombia. Therya 5:567573.

Estrada, A., R. Coates-Estrada, D. Meritt, S. Montiel, and D. CuRIEL. 1993. Patterns of Frugivore Species Richness and Abundance in Forest Islands and in Agricultural Habitats at Los Tuxtlas, Mexico. Vegetatio 107:245-257.

Gallina, S., S. Mandujano, and A. González-Romero. 1996. Conservation of mammalian biodiversity in coffee plantations of Central Veracruz, Mexico. Agroforestry Systems 33:13-27.

GLobal Biodiversity Information Facility. 2019. GBIF occurrence download. https://www.gbif.org/species/5218906. Accessed in January 05, 2019.

González-Christen, A. 2008. La diversidad, alfa, beta y gama de la mastofauna en la Sierra de Santa Marta, Veracruz, México. Pp. 103-123 in Avances en el estudio de los mamíferos de México, Volumen II (Lorenzo, C., E. Espinoza, and J. Ortega, eds.). Asociación Mexicana Mastozoología A. C. Ciudad de México, México.

González-Medrano, F. 2005. La Vegetación. Pp. 88-106 in Historia Natural de la Reserva de la Biosfera El Cielo, Tamaulipas, México (Sánchez-Ramos, G., P. Reyes-Castillo, y R. Dirzo, eds.). Universidad Autónoma de Tamaulipas. Hong Kong, China.

Hernández-Hernández, J., C. Chávez, and L. Rurik. 2018. Diversidad y patrones de actividad de mamíferos medianos y grandes en la Reserva de la Biosfera La Encrucijada, Chiapas, México. Revista de Biología Tropical 66:634-646.

Hodge, A., AND B. Arbogast. 2016. Carnivore diversity at a montane rainforest site in Ecuador's Gran Sumaco Biosphere Reserve. Oryx 50:474-479.

Mandujano, S., E. López-Tello, and L. Pérez-Solano. 2018. Mamíferos medianos y grandes asociados al bosque tropical seco del centro de México. Revista de Biología Tropical 66:1232-1243.

Olguín-Monroy, H. C., L. León-Paniagua, U. M. Samper-Palacios, and V. Sánchez-Cordero. 2008. Mastofauna de la región de los Chimalapas, Oaxaca, México. Pp. 165-216 in Avances en el estudio de los mamíferos de México, Volumen II (Lorenzo, C., E. Espinoza, and J. Ortega, eds.). Asociación Mexicana de Mastozoología, A. C., Ciudad de México, México.

Pérez, M. E., and S. Valencia-A. 2017. Estudio preliminar del género Quercus (Fagaceae) en Tamaulipas, México. Acta Botánica Mexicana 120:59-111.

Ramírez-Pulido, J., N. González-Ruiz, and H. H. Genoways. 2005. Carnivores from the Mexican state of Puebla: distribution, taxonomy, and conservation. Mastozoología Neotropical 12:37-52.

Secretaría de Medio Ambiente y Recursos Naturales (Semarnat). 2010. Norma Oficial Mexicana NOM-059-SEMARNAT-2010. Protección ambiental, especies de flora y fauna silvestres de México, categorías de riesgo y especificaciones para su inclusión, exclusión o cambio, y lista de especies en riesgo, Diario Oficial de la Federación México. Accessed in November 24, 2018. 
Steinberg, M., M. Taylor, and K. Kinney. 2014. The El Cielo Biosphere Reserve: forest cover changes and conservation attitudes in an important Neotropical region. The professional geographer 66:403-411.

Vargas-Contreras, J. A., and A. Hernández-Huerta. 2001. Distribución altitudinal de la mastofauna en la Reserva de la Biosfera "El Cielo", Tamaulipas, México. Acta Zoológica Mexicana 82:83-109.

Yensen, E., And T. Tarifa. 2003. Galictis vitatta. Mammalian Species 727:1-8.

Tarifa, T., E. Yensen, B. Rios-Uzeda, V. Zambrana, P. Van-Damme, and R. Wallace. 2010. Mustelidae. Pp. 447- 481 in Distribución, Ecología y Conservación de los Mamíferos Medianos y Grandes de Bolivia (Wallace, R., H. Gómez, Z. Porcel, and D. Rumiz, eds.). Centro de Ecología Difusión Simon I Patiño. Santa Cruz de la Sierra, Bolivia.

Associated editor: Consuelo Lorenzo

Submitted: December 18, 2019; Reviewed: January 8, 2020.

Accepted:January 10, 2020; Published on line:March 2, 2020. 